\title{
Haemosiderosis as a Consequence of Haemolysis and Repeated Blood Transfusion following Arsenic Intoxication in a Child
}

\author{
A AFROZE ${ }^{a}$, M RUKUNUZZAMAN $^{\mathrm{b}}, \mathrm{S}_{\mathrm{SASANC}}$ A RAHMAN $^{\mathrm{d}}$
}

\begin{abstract}
Summary:
Arsenic is an ubiquitous element detected in low concentration virtually in all environmental media. Arsenic intoxication may occur following ingestion, inhalation or contact. A 51/2 years old girl with arsenic intoxication and haemosiderosis was admitted in the department of Paediatric Gastroenterology and Nutrition, Bangabandhu Sheikh Mujib Medical University. In Bangladesh 54 out of 64 districts are affected by arsenic contamination in tubewell water. 35 million people are at risk of arsenic toxicity. This patient presented with history of repeated blood
\end{abstract}

\section{Introduction:}

Arsenic is an ubiquitous element detected in low concentration in virtually all environmental media ${ }^{1}$. Arsenic remains in two forms -organic and inorganic ${ }^{2}$. Organic arsenic is usually taken with food and is known to be least toxic. But drinking water derived from underground source contains arsenic in inorganic form. This is known to have higher toxicity and is significantly hazardous for human health. Exposure to arsenic compound may follow inhalation and contact during occupational exposure of metal workers or workers engaged in the manufacturing of fertilizers and pesticides. In Bangladesh people depends primarily on rice for their calorie intake (about $70 \%$ of daily in take). Study suggests that rice

a. Professor Ainun Afroze, Professor \& Head, Dept. of Paediatric Gastroenterology \& Nutrition, BSMMU.

b. Dr. M Rukunuzzaman, Assistant Professor, Dept.of Paediatric Gastroenterology \& Nutrition, BSMMU

c. Dr. S Hasan, Medical Officer, Dept. of Paediatric Gastroenterology $\&$ Nutrition, BSMMU.

d. Dr. A Rahman, Assistant Professor, of Paediatric Gastroenterology \& Nutrition, BSMMU.

Address of Correspondence: Professor Ainun Afroze, Professor \& Head, Dept. of Paediatric Gastroenterology \& Nutrition, Bangabandhu Sheikh Mujib Medical University, Dhaka, E-mail: ainunafroze@yahoo.com

Received: 7 March, 2007

Accepted: 8 March, 2008 transfusion since 4 months of age associated with fever, Jaundice and abdominal pain. She also had anaemia and hepatosplenomegaly. She had high arsenic level in urine and hair samples. Haemosiderosis was diagnosed by liver biopsy. She was treated with Desferrioxamine, antioxidant vitamins (Vit A, E), zinc and blood transfusion. In the present case haemolysis due to arsenic intoxication occurred at an early age, for which frequent blood transfusions were needed. Multiple transfusion without proper chealation led to development of haemosiderosis.

(J Bangladesh Coll Phys Surg 2008; 26: 149-152)

is an important dietary source of arsenic toxicity because it consumes arsenic from water during cooking. They also drink tube-well water as a source of safe water which contains arsenic in many areas ${ }^{3}$.

Arsenic toxicity is identified as a public health problem throughout the world. In many countries of the world, arsenic in drinking water has been detected at a concentration higher than the accepted level of $0.01 \mathrm{mg} / \mathrm{L}^{4}$. These are Bangladesh, Argentina, Australia, Chile, China, Hungary, India, Mexico, Peru, Thailand \& USA. Countries where adverse health effects have been documented also include Bangladesh, India, China \& $\mathrm{USA}^{5}$. In Bangladesh fifty four out of total sixty four districts are affected by arsenic contamination in tube well water 6 . The arsenic level of $46 \%$ of the samples taken in 64 districts were above safe level i,e $0.01 \mathrm{mg} / \mathrm{L}^{7}$. As a result 35 million people are at risk of arsenic toxicity in Bangladesh only. In 1993 arsenic intoxication was first identified in Chapai Nawabganj district of Bangladesh by NIPSOM ${ }^{8}$.

Till date no case has yet been reported about haemosiderosis occurring as a consequence of arsenic intoxication. The authors would like to share the experience of managing a girl who presented with progressive pallor, mild jaundice and hepato splenomegaly since 4 months of age. She was provisionally thought to be a case of congenital 
haemolytic anemia. For that she received frequent blood transfusion which led to the development of haemosiderosis of liver.

\section{Case Report:}

A $5^{1 / 2}$ years old girl of non-consanguinous parents was admitted in Paediatric Nutrition and Gastroenterology unit of BSMMU with the history of repeated blood transfusion since 4 months of age. She had fever for 5 months, Jaundice for 15 days and pain in right side of abdomen for 10 days. She received repeated blood transfusion initially at 3 months interval but monthly during last 2 years. She received inadequate doses of oral desferrioxamine. For the last 5 months she developed irregular fever without any evening peak associated with anorexia, weakness and pallor. She also developed Jaundice for the last 15 days which was gradually deepening.

Her mother had history of repeated abortion and was diagnosed as a case of chronic arsenicosis since her adolescence but was not treated accordingly. Two of her maternal aunts gave history of primary sterility. They used tubewell water for drinking and other household purposes. Subsequently the tubewell water was identified as having high arsenic content by survey of health authority.

On examination she was pale, icteric $\&$ her weight was just below $10^{\text {th }}$ centile. Her abdomen was distended with hepatosplenomegaly. There was no ascites. Her vital signs were within normal limit.

She had white cells count of $10 \times 10 \% / \mathrm{L}$ (Neutrophil $55 \%$, Lymphocyte $35 \%$, Monocyte 5\%, Eosinophil $5 \%$ ) with platelets count of $180 \times 10 \% / 2$. Her haemoglobin was $8.5 \mathrm{gm} / \mathrm{dl}$, HCT $25 \%$, MCV $70 \mathrm{fl}$, MCH $24 \mathrm{pg}, \mathrm{MCHC} 34 \mathrm{gm} / \mathrm{dl}$ and 3\% reticulocyte count. The peripheral blood film showed anisopoikilocytosis with microcytic hypochromic anaemia with many nucleated RBCs, pencil cells, \& teardrop cells. The arsenic level of her urine and hair were $800 \mu \mathrm{g} / \mathrm{L}$ and $15.6 \mu \mathrm{g} / \mathrm{g}$ respectively. (Normal level of arsenic in urine and hair are 0.005-0.04 mg/L and $0.08-0.25 \mathrm{mg} / \mathrm{Kg}$ respectively).

Blood chemistry revealed bilirubin $13.7 \mathrm{mg} / \mathrm{dl}$, ALT $542 \mathrm{U} / \mathrm{L}$, Random blood sugar was $4.5 \mathrm{mmol} / \mathrm{L}$, serum iron-172 $\mu \mathrm{mol} / \mathrm{L}$, serum ferritin-1007495 $\mu \mathrm{g} / \mathrm{l}$
(1000 times higher than normal), serum Iron Binding Capacity was $49.8 \mu \mathrm{mol} / \mathrm{L}$, serum Ceruloplasmin 63.4 $\mathrm{mg} / \mathrm{dl}$. Her coagulation profile revealed prothrombin time $14.7 \mathrm{sec}$ with INR 1.25 and normal bleeding \& clotting time. Hepatitis A, B, and C viral markers were all negative. USG of whole abdomen showed hepatosplenomegaly with reduced hepatic echotexture of the liver. ANA was also negative. Both direct and indirect coomb's tests were negative. Osmotic fragility of RBC was normal. Haemoglobin electrophoresis was normal. Bone marrow biopsy showed erythroid hyperplasia.

Biopsy of liver tissue revealed loss of lobular architecture, marked expansion of portal area with periportal fibrosis, bridging fibrosis and marked deposition of haemosiderin in hepatocytes, Kupffer cells \& in fibrous tissue blands. All these features were highly suggestive of haemosiderosis progressing to cirrhosis. (Fig-1)

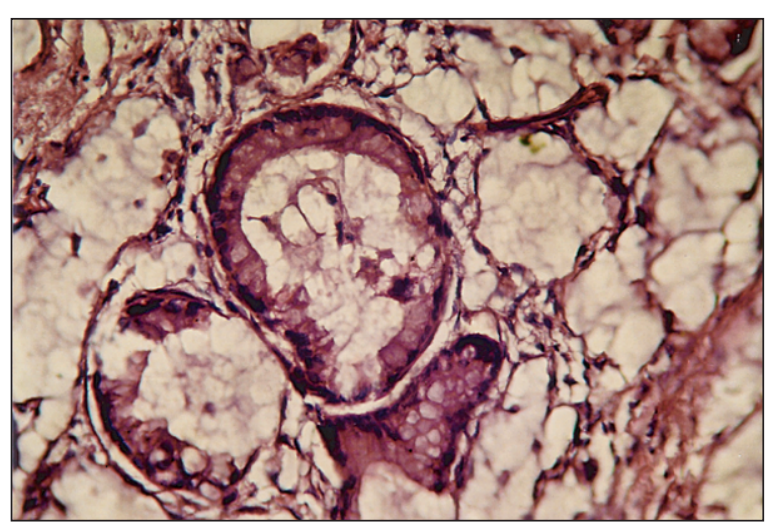

Fig-1: Biopsy of the liver tissue.

The patient was managed with Desferrioxamine, antioxidant vitamins (vit A, E), and zinc. She needed two units of blood transfusion during current admission.

\section{Discussion:}

In order to establish the relationship between arsenic intoxication and hemolysis a thorough literature search was carried out. It was described that arsenic compounds after absorption through either GIT or skin are readily taken up by red blood cells. It is then deposited in the liver, kidney, muscle, bone, skin and hair. After exposure, arsenic enters the red blood cells and causes membrane instability leading to massive 
haemolysis. It poisons the enzymatic process vital to the cell metabolism and decrease ATP production with inhibition of glycolytic pathway 9,10 . In presented patient the skin pigmentation, arthropathy, cardiac involvement and portal hypertension has not yet developed.

Acute arsenic intoxication presents with gastrointestinal symptoms eg nausea, vomiting, diarrhea and haemolysis. Neurological symptoms eg peripheral neuropathy, seizure or coma and other manifestations eg facial oedema, intravascular haemolysis, hepatomegaly, renal failure and circulatory collapse may also occur in acute arsenic intoxication $^{11}$. Chronic arsenic intoxication is associated with various haematological changes, peripheral neuropathy, various skin changes and hepatocellular damage ${ }^{12}$. Haematological changes include anaemia, neutropenia \& thrombocytopenia. Anaemia is mostly due to haemolysis. High serum bilirubin level is due to haemolysis and hepatocellular damage. Epidemiological studies have shown an association between malignancies such as skin cancer, lung cancer, leukaemia \& lymphoma with $\operatorname{arsenic}_{\text {intoxication }}{ }^{13}$.

Presented patient ingested arsenic contaminated water, rice and other food grains since early childhood. She was breastfed by her arsenic intoxicated mother. As the child is exposed to a very high arsenic level from intrauterine life, features of arsenic intoxication developed at an early age of 4 months. Haemolytic manifestations may occur both in acute and chronic intoxication. High hair arsenic level is considered to reflect chronic intoxication. On the other hand intravascular haemolysis and high urinary concentration of arsenic were considered to reflect acute intoxication. The most useful laboratory test for confirming arsenic intoxication is the urinary arsenic level ${ }^{14}$. Non-exposed persons have levels below $10 \mathrm{gm} / \mathrm{g}$ of creatinine while persons exposed to $0.01 \mathrm{mg} / \mathrm{L}$ of arsenic, have levels of $50 \mathrm{~g} / \mathrm{g}$ of creatinine. Acute poisoning is caused at $1000 \mathrm{gm} / \mathrm{gm}$ of creatinine or higher levels. Another diagnostic method for arsenic intoxication is measuring arsenic level in the hair $\&$ nail $^{15}$.

Therapeutic red cell exchange is used to treat patients with haemolytic anaemia due to arsenic intoxication despite insufficient evidence of its effectiveness ${ }^{16}$. In addition, chealating agents including Dpenicillamine and dimercaprol are used in chronic arsenic poisoning. Vitamins and antioxidants are also used for the treatment of chronic arsenic intoxication $^{17}$.

\section{Conclusion:}

Children who present with anaemia, Jaundice \& history of repeated blood transfusion is usually considered as suffering from congenital haemolytic anaemia . A high level of suspicion coupled with arsenic endemicity may help us to make an early diagnosis of hemolytic anaemia due to arsenic toxicity. A coincidental finding of arsenicosis in the palms and soles of the attending mother, raised the suspicion of arsenicosis in presented patient. In depth sociodemographic history and enquiry of family members provided clue to the diagnosis. Careful investigation of the patient helped us to diagnose the child as having haemosiderosis due to repeated blood transfusion for haemolysis caused by arsenic intoxication.

Inspite of having anaemia \& impaired hepatic function, the patient improved by conservative management. She was discharged with antioxidants, chealating agent, zinc and proper counseling to the parents.

\section{References:}

1. Paul B. Tchounwou, Anita K. Patlolla, Jose A. centano. Carcinogenic \& systemic Health Effects Associated with Arsenic Exposure- A Critical Review. Toxicologic Pathology 2003; 31: 575-588.

2. Je Jung Lee, Yeo-Kyeoung Kim, Sang Hee cho, Kyeong Soo park, IK-Joo chung. Haemolytic Anaemia as a Sequele of Arsenic Intoxication Following Long- Term Ingestion of Traditional Chinese Medicine. J Korean Med sci 2004; 19 : 127-9.

3. Munjoo Bae, Chiho watanabe, Tsukasa Inaoka, Makiko Sekiyama, Noriko Sudo, Mozammel Hoque Bokul, Ryutaro ohtsuka. Arsenic in cooked rice in Bangladesh. Lancet 2002; 360: 1839-40.

4. Abernathy co, Liu YP, Longfellow D, Aposhian HV, Beck B, Fowler B, Goyer R, Menzer R, Rossman T, Thompson C, waalker M. Arsenic: Health effects, Mechanisms of actions and research issues. Environ Health prospect1999; 107: 593-597.

5. Who. Arsenic in drinking water. Fact sheet No 210, Revised May 2001. 
6. A W Khan, SK A Ahmed, A. Hadi, M H Faruquee, M H Khan. Arsenic: Silent catastrophe. Environment on Health, Bulletin 1997; 1: 2-5.

7. Watanabe $\mathrm{C}$, Inaoka $\mathrm{T}$, Kadono $\mathrm{T}$ et al. Males in rural Bangladeshi communities are more susceptible to chronic arsenic poisoning than females: analyses based on urinary arsenic. Environ Health prospect 2001; 109: 1265-70.

8. Cuncha J, Pereira L, pun MI, LopesV, Vong SK. Arsenic and acute lethal intoxication. Hong Kong pharm J 1998; 7: 50-3.

9. Behrman RE, Kliegman RM, Jenson HB. Nelson Textbook of Paediatrics. 17th ed. India. ELSEVIER.2000: P 2355-8.

10. Concha G, Vogler G, Nermell B, Vahter M. Low-level arsenic excretion in breast milk of native Andean women exposed to high levels of arsenic in the drinking water. Int arch occup Environ Health 1998; 71: 42-46.

11. Armstrong CW, Stroube R, Rubio T. Outbreak of fatal arsenic poisoning caused by contaminated drinking water. Arch Environ health 1984; 39: 276-279.
12. Aschengrau A, Zierler S, cohen A. Quality of community drinking water and the occurrence of spontaneous abortion. Arch Environ health 1989; 44: 283-290.

13. Bates MN. Smith AH, Hopenhayn Rich C. Arsenic ingestion and internal cancers: a review. Am J Epidemiol 1992; 135: 462-76.

14. Wong ST, Chan HL, Teo SK. The spectrum of cutaneous and internal malignancies in chronic arsenic toxicity. Singapore Med J 1998; 39: 171-3.

15. Johnson LR, Farmer JG. Use of human metabolic studies and urinary arsenic speciation in assessing arsenic exposure. Bull Environ contam Toxicol 1991; 46: 53-61.

16. Hall AH. Chronic Arsenic poisoning. Toxicol Lett 2002; 128: 69-72.

17. Ernst E. Toxic heavy metals and undeclared drugs in Asian herbal medicines. Trends pharmacol sci 2002; 23: 136-9. 